\title{
ROLE OF FINE NEEDLE ASPIRATION CYTOLOGY (FNAC) IN THE DIAGNOSIS OF SKIN AND SUBCUTANEOUS LESIONS: A RETROSPECTIVE ANALYSIS
}

\author{
Gautam Mazumder', Sanjay Nath²
}

${ }_{1}^{1}$ Associate Professor, Department of Dermatology, Tripura Medical College \& Dr. BRAM Teaching Hospital, Agartala. ${ }^{2}$ Associate Professor, Department of Pathology, Tripura Medical College \& Dr. BRAM Teaching Hospital, Agartala.

\begin{abstract}
BACKGROUND

Cytopathology of skin has been established to be useful in the diagnosis of several skin lesions. This study aims to evaluate cytopathology as a quick non-invasive method for early diagnosis of different skin conditions including neoplastic and nonneoplastic. Fine Needle Aspiration Cytology (FNAC) is a simple and rapid diagnostic technique. The present study is a retrospective analysis of 356 patients who were cytologically evaluated for various skin and superficial soft tissue lesions over a period of four years (W. E. F. January 2012 to December 2015) in the Department of Dermatology and Pathology of Tripura Medical College and Dr. BRAM Teaching Hospital. Amongst the 356 cases reported, 170 cases were non-neoplastic and 186 were reported as neoplastic skin lesions. Out of 186 neoplastic lesions, 134 (72.04\%) were benign in nature and rest of the cases were malignant, i.e. only 52 cases $(27.95 \%)$. Commonest non-neoplastic lesion epidermal inclusion cyst followed by acute suppurative lesions. Other lesions which were commonly reported in our study were Granulomatous lesions. It has been observed that FNAC performed carefully, skilfully with proper selection of cases leads to an early diagnosis in majority of the skin lesions.
\end{abstract}

\section{KEYWORDS}

Fine Needle Aspiration Cytology (FNAC), Skin Lesions, Skin Tumours.

HOW TO CITE THIS ARTICLE: Mazumder G, Nath S. Role of fine needle aspiration cytology (FNAC) in the diagnosis of skin and subcutaneous lesions: a retrospective analysis. J Evolution Med Dent Sci 2016;5(5):292-295, DOI: 10.14260/jemds/2016/63

\section{INTRODUCTION}

Fine Needle Aspiration Cytology (FNAC) is a simple and rapid diagnostic technique. Due to early availability of results, minimal trauma and complications, fine needle aspiration cytology is now considered a valuable diagnostic aid.[1]

It was earlier mostly used in the diagnosis of different surgical conditions only. However, now-a-day its utility has been expanded to diagnose different skin conditions to avoid wide excision biopsy in diagnostic dilemmas. Biopsy or surgical excision of the lesion provides the specimen for histopathological examination, which is the mainstay for diagnosis. Fine-needle aspiration cytology on the other hand is an even simpler procedure, which can provide accurate diagnosis to confirm or exclude the malignancy. ${ }^{[2]}$ This study emphasises the cytomorphological variations of different cutaneous and subcutaneous lesions in a tertiary care centre of North East India in a duration of four years.

\section{MATERIALS AND METHODS}

In the present study, a total number of 356 patients were cytologically evaluated who has been presented with various skin and superficial soft tissue lesions during the time period from January 2012 to December 2015 (Four years) in the Department of Dermatology, Tripura Medical College and Dr. BRAM Teaching Hospital. The study pattern was retrospective.

Financial or Other, Competing Interest: None

Submission 05-01-2016, Peer Review 06-01-2016,

Acceptance 11-01-2016, Published 18-01-2016.

Corresponding Author:

Dr. Gautam Mazumder,

Associate Professor, Department of Dermatology,

Tripura Medical College \&

Dr. B. R. Ambedkar Memorial Teaching Hospital,

Hapania, P. O. ONGC Colony,

Agartala-799014.

E-mail: drgautam2112@yahoo.com

DOI:10.14260/jemds/2016/63
All the cases underwent for Fine Needle Aspiration Cytology (FNAC) were only included in the study. Skin scraping was done for superficial ulcers and ulcerated tumors.

The spectrum of cytological pattern has been recorded. A detailed history of the patients was taken and physical examination findings were recorded. Data regarding relevant radiological, biochemical and haematological investigations done for diagnostic purposes were collected. Under aseptic precautions, fine needle aspirations were performed using a 21 -gauge needle by palpation by pathologists. For most of the cases a single pass well sufficed. For larger lesions, 2 or 3 separate passes were made. All the slides were routinely stained with May-Grunwald Giemsa (MGG). Stains like Haematoxylins and Eosin (H and E), PAP, Ziehl-Neelsen stain were used wherever felt necessary. The study was approved by the Institutional Ethics Committee.

\section{RESULTS AND OBSERVATIONS}

Out of the 356 patients studied, 208 patients (58.42\%) were male and 148 (41.57\%) were female with a male-to-female ratio of 1.40:1. The youngest patient was 4 years old, who was presented with a vascular lesion and the oldest being 72 years presented with epidermal inclusion cyst (Table I). There were 170 (47.75\%) non-neoplastic lesions and 186 (52.24\%) neoplastic.

\begin{tabular}{|c|c|c|c|c|c|c|}
\hline $\begin{array}{c}\text { Sl. } \\
\text { No. }\end{array}$ & Sex & $\begin{array}{c}\text { No. } \\
\text { of Cases }\end{array}$ & $\mathbf{0 - 2 0}$ & $\mathbf{2 1 - 4 0}$ & $\mathbf{4 1 - 6 0}$ & $>\mathbf{6 0}$ \\
\hline 1 & Male & 208 & 28 & 62 & 86 & 32 \\
\hline 2 & Female & 148 & 23 & 58 & 32 & 35 \\
\hline 3 & Total & 356 & 51 & 120 & 118 & 67 \\
\hline
\end{tabular}

Amongst the 356 cases reported, 170 cases were non-neoplastic and 186 were reported as neoplastic skin lesions. 
Out of 186 neoplastic lesions, 134 (72.04\%) were benign in nature and rest of the cases were malignant, i.e. only 52 cases $(27.95 \%)$.

Most frequently encountered non neoplastic lesion in our present study was epidermal inclusion cyst, (Fig: 1), (87; 51.17\%). The second most common lesion was Acute Suppurative Lesion $(54 ; 31.76 \%)$. Other lesions which were commonly reported in our study were Granulomatous lesion (24; 14.11\%), Ganglion, Fig: 2 (5; 2.94\%).

Lipoma was the most common lesion amongst all neoplastic benign lesions, Fig: 3 (138; 81.65\%) followed by benign spindle cell tumour, Fig: 4 (26; 15.38\%), Vascular lesion $(5 ; 2.95 \%)$.

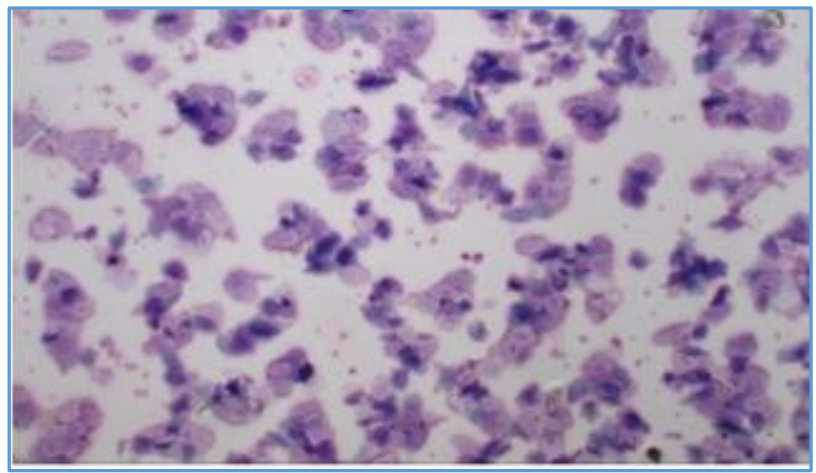

Fig. 1: Epidermal Inclusion cyst, sebaceous cyst showing plenty of anucleated squames with few mature squamous cells. (May-Grunwald Giemsa) 40x

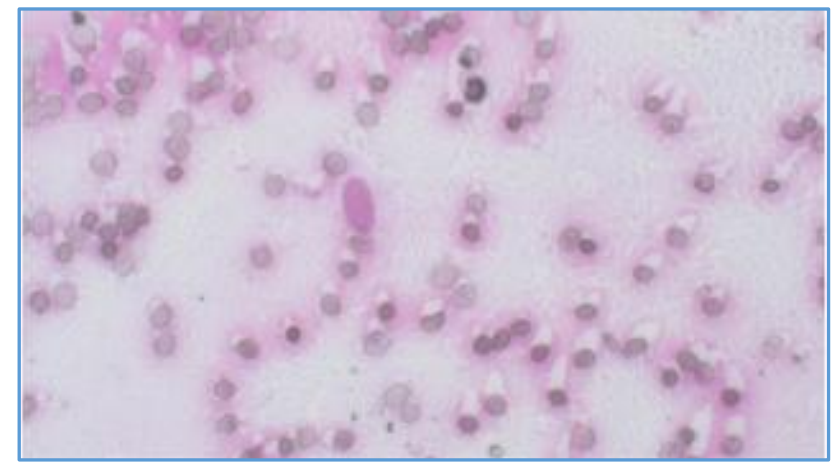

Fig. 2: Ganglion Cyst showing a single cell with abundant cytoplasm and small oval nuclei in a myxoid background. (May-Grunwald Giemsa) 40x

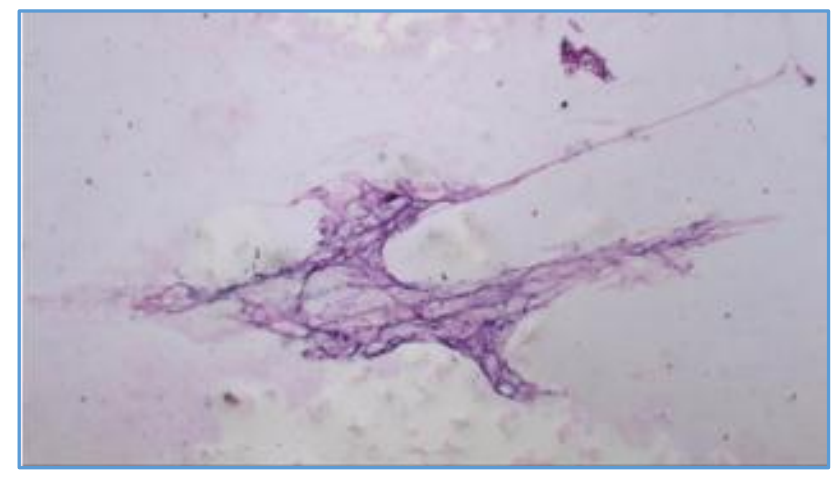

Fig. 3: Lipoma showing large monovaculated adipocytes with scanty fibrous stroma. (Leishman Giemsa) $40 \mathrm{x}$

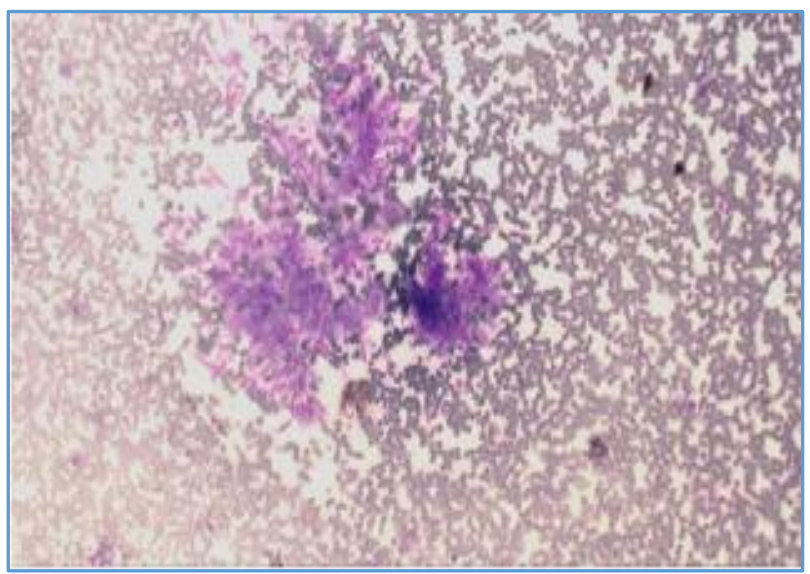

Fig. 4: Spindle cell neoplasm showing cells with spindle shaped nuclei in a myxoid background. (May-Grunwald Giemsa) 40x

\begin{tabular}{|c|c|c|}
\hline Type & $\begin{array}{l}\text { No. of } \\
\text { cases }\end{array}$ & Percentage (\%) \\
\hline Lipoma & 138 & 81.65 \\
\hline Benign Spindle Cell Tumour & 26 & 15.38 \\
\hline Vascular Lesions & 5 & 2.68 \\
\hline Total & 169 & 100 \\
\hline \multicolumn{3}{|c|}{ Table 2: Distribution of Benign Neoplasm } \\
\hline
\end{tabular}

There were 17 malignant neoplastic lesions have been reported in this one and half year study. Amongst which the commonest lesion was squamous cell carcinoma, Fig: 5 (11; $64.70 \%)$ followed by adenocarcinoma, Fig: 6 (2; 11.76\%). The cases of adenocarcinoma were presented as a nodule over laparotomy scar in two patients. Three cases were reported as malignant spindle cell tumor, Fig: 7 (3; 17.64\%). We have found a solitary case of cutaneous T-Cell lymphoma, (1; 5.88\%). Fig: 8 presented as multiple nodular lesions over the face, scalp and neck.

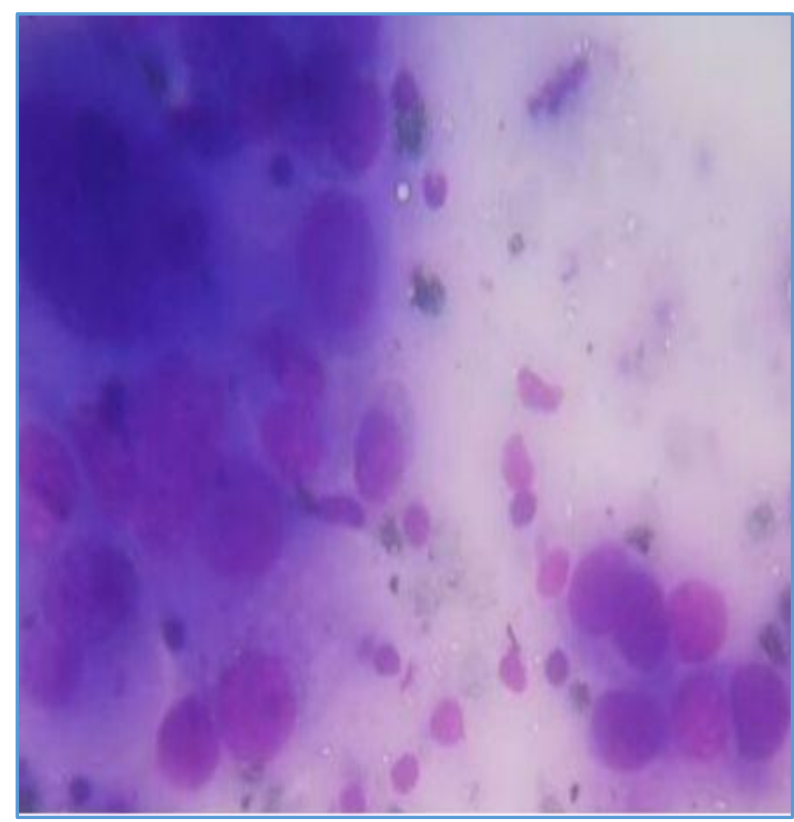

Fig. 5: Metastatic squamous cell carcinoma showing clear blue cytoplasmic staining, indicating squamous differentiation. (May-Grunwald Giemsa) 40x 


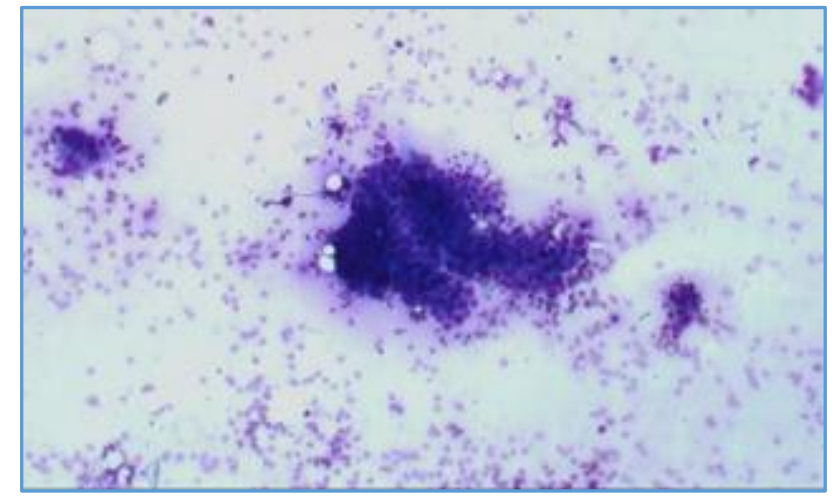

Fig. 6: Metastatic adenocarcinoma showing glandular cells, pleomorphic in nature and arranged in monolayer sheets (May-Grunwald Giemsa) 40x

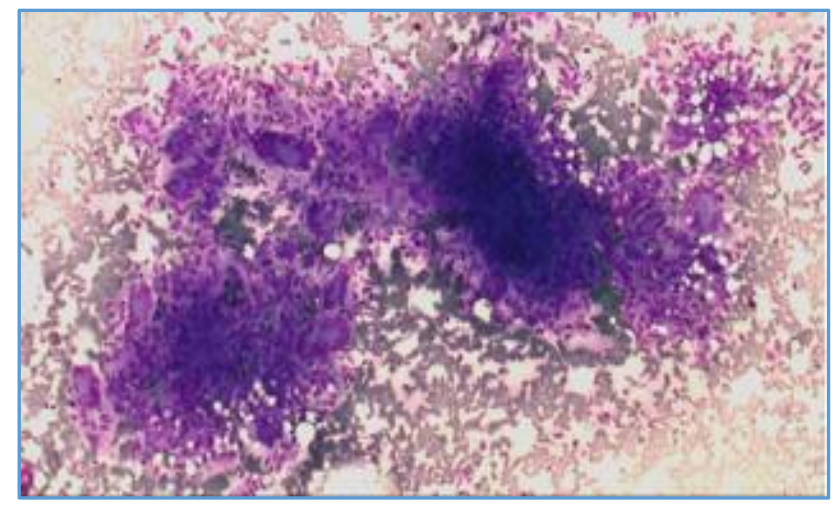

Fig. 7: Giant cell tumour of tendon sheath showing moderately cellular smear of mainly single plump spindle cells with oval bland nuclei, a couple of multinucleated giant cells are noted

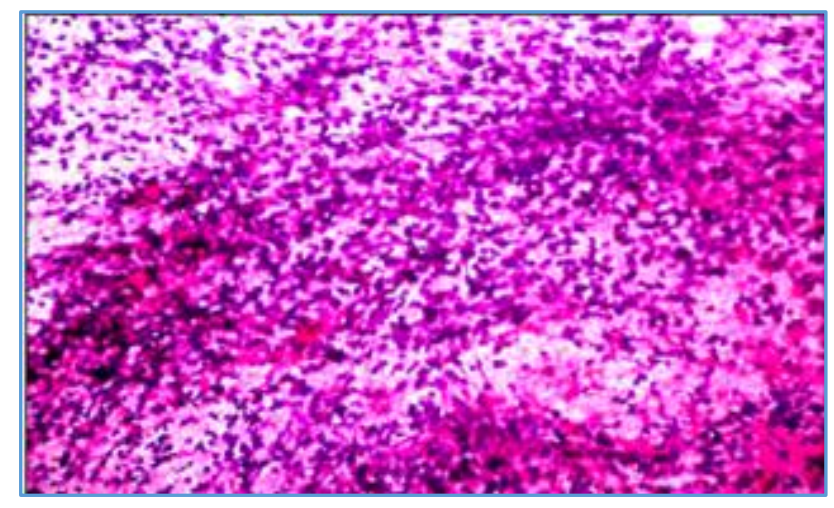

Fig. 8: Cutaneous T cell Lymphoma showing monomorphic population of cell with high nucleo-cytoplasmic ratio

\begin{tabular}{|c|c|c|}
\hline Type & $\begin{array}{c}\text { No. } \\
\text { of } \\
\text { Cases }\end{array}$ & $\begin{array}{c}\text { Percentage } \\
\text { (\%) }\end{array}$ \\
\hline Squamous Cell Carcinoma & 11 & 64.70 \\
\hline Adenocarcinoma & 02 & 11.76 \\
\hline Malignant spindle cell tumour & 03 & 17.64 \\
\hline $\begin{array}{c}\text { Metastatic Cutaneous T-Cell } \\
\text { lymphoma }\end{array}$ & 01 & 05.88 \\
\hline \multicolumn{2}{|c|}{ Table 3: Distribution of malignant neoplasms } \\
\hline
\end{tabular}

\section{DISCUSSION}

Skin is the largest organ in the body and is the site for variety of skin lesions including inflammatory, tumour-like benign and malignant lesions. The nodular lesions-hamartomatous, inflammatory, reactive and neoplastic that occur in skin are more numerous than those produced by any other organ. ${ }^{3]}$

In the current era where the needle is preceding the scalpel' as surgical tissue biopsy becomes increasingly expensive, it seems practical to discuss the role and scope of FNAC in diagnosing skin and soft tissue tumours. [4] It was seen that biopsy provided complete tissue details for accurate diagnosis; however, diagnosis takes a longer time as compared to the early diagnosis provided by cytology.[5]

In the present retrospective study, total 356 cases have been evaluated cytologically. Amongst 170 cases were nonneoplastic and 186 cases were neoplastic in nature. Epidermal inclusion cyst was the commonest lesion of all non-neoplastic lesions (51.17\%). Other common lesions were acute suppurative lesion (31.76\%), ganglion (2.94\%) and granulomatous lesion (14.11\%). The observations are similar as other Indian study done by Bhowmik et al.[5] Discussing about the benign neoplasms, lipoma has been reported as the commonest lesion (81.65\%). Bezabih et al.[6] also reported lipoma (70.5\%) as the most common benign cutaneous lesion. The second most common benign lesion was benign spindle cell tumour (15.38\%) in our study. However, Nagira et al.[7] reported the most common benign STT as spindle cell (31.5\%) followed by lipomatous tumor $(14.6 \%)$. This variation in results may be due to higher sample size in our study.

There were $2.68 \%$ cases reported as tumours of vascular origin. A total number of 17 cases of malignant neoplasms were diagnosed in our study, which were presented as cutaneous nodules. Out of 17 cases, 14 were metastatic in origin. Metastatic squamous cell carcinoma was reported in 11 cases where primary was found to be a lung mass followed by 2 cases of adenocarcinoma on laparotomy scar with a primary in post cholecystectomy stump. A solitary case of metastatic cutaneous lymphoma has also been reported in our study. Cutaneous metastasis is a rare occurrence and usually a sign of terminal stage of malignant disease. In a study by Sharma et al. reported multiple metastatic site involvement in $9 \%$ cases. ${ }^{\left[{ }^{8]}\right.}$ As primary cutaneous malignant lesion we reported 3 cases of malignant spindle cell tumours (17.64\%), which correlates with study done by Beg et al. showed $16.7 \%$ of malignant spindle cell tumour.[9]

\section{CONCLUSION}

Cytology (FNAC) performed carefully, skilfully with proper selection of cases leads to an early diagnosis in majority of the skin lesions. FNAC is a rapid, safe, cost effective modality of determining the nature of a palpable skin lesion and avoids more invasive and costly methods of investigation. Our study also emphasised on the fact that FNAC was preferred over biopsy for quick diagnosis, especially in those patients who are suffering debilitating diseases. The only limitation of the technique is low yield in some of the cases.

\section{REFERENCES}

1. Ahmad $S$ et al. Study of fine aspiration cytology in lymphadenopathy with special reference to Acid Fast Staining in cases of Tuberculosis. JK Science. 2005;1:1-4.

2. Kassi et al. The role of Fine-Needle Aspiration Cytology in the Diagnosis of Basal Cell Carcinoma. International Scholarly Research Network ISRN Dermatology Volume 2012, Article ID 132196, 2 pages. 
3. Singh et al. Clinical and cytohistopathological evaluation of inflammatory skin lesions in and around Muzaffarnagar district. Indian Journal of Basic and Applied Medical Research; March 2015: Vol.-4, Issue-2, P. 87-92.

4. Rekhi B, Gorad BD, Kakade AC, et al. Scope of FNAC in the diagnosis of soft tissue tumors-A study from a tertiary cancer referral center in India. Cytojournal. 2007;4:20.

5. Bhowmik et al. Role of Fine Needle Aspiration Cytology in the diagnosis of skin and superficial soft tissue lesions: a study of 510 cases. Turkish Journal of Pathology. Vol. 31, No. 3, 2015; Page 200-205.
6. Bezabih M. Cytological diagnosis of soft tissue tumors. Pathologe. 2007:368-76. S:28.

7. Nagira K, Yamamoto T, Akisue T, et al. Reliability of fineneedle aspiration biopsy in the initial diagnosis of softtissue lesions. Diagn Cytopathol. 2002;27:354-61.

8. Sharma S, Kotru M, Yadav A, et al. Role of fine needle aspiration cytology in evaluation of cutaneous metastasis. Diagn Cytopathol. 2009;37:876-80.

9. Beg S, Vasenwala SM, Haider N, et al. A comparison of cytological and histopathological findings and role of immunostains in the diagnosis of soft tissue tumors. J Cytol. 2012;29:125-30. 